\title{
Aprendizaje integrado de contenido y lenguaje en la carrera Ingeniería Agrónoma de la Universidad de Guantánamo ${ }^{1}$
}

\author{
Mg. Zoila González Cantalapiedra²
}

\begin{abstract}
RESUMEN
Este artículo presenta valoraciones acerca de la eficacia del enfoque metodológico del aprendizaje integrado de contenido y lenguaje (AICLE). La primera parte presenta aspectos relacionados con la investigación y documentación sobre literatura relacionada con el enfoque metodológico AICLE; la segunda comenta los resultados obtenidos de la implementación de clases con esta metodología en una investigación llevada a cabo por la autora, en las clases de inglés como lengua extranjera (ILE) a los estudiantes de segundo año en la carrera Ingeniería Agrónoma de la Universidad de Guantánamo, con el objetivo de presentar temas y contenidos a los estudiantes de modo más atractivo y efectivo en las clases de lengua extranjera.
\end{abstract}

Palabras clave: ILE, AICLE, Ingeniería Agrónoma, Universidad de Guantánamo.

\section{Integrated content and language learning in the Agronomy Engineering major of the University of Guantanamo}

\begin{abstract}
The paper discusses some ideas about the effectiveness of the methodological approach to integrated content and language learning (CLIL). A first part analyzes aspects related to the CLIL methodological approach and the second comments the results obtained by implementing in the lessons the CLIL methodology, as part of a research carried out by the author while teaching English as a foreign language (EFL) lessons to sophomore students majoring in Agronomy Engineering at the University of Guantánamo, with the aim of delivering agronomy- related content in a more attractive and effective way inside the foreign language class.
\end{abstract}

Keywords: ESL, CLIL, Agronomy Engineering, University of Guantanamo.

I Este artículo es parte de una investigación que desarrolla la autora, basada en su experiencia como profesora de ILE para el Centro Gestor de Idiomas de la Universidad de Guantánamo, en aras de mejorar su práctica docente y contribuir a la implementación de la política de perfeccionamiento de la educación superior en Cuba con el Plan de Estudios E.

2 Magíster en Lengua Inglesa. Profesora de ILE, colaboradora del Centro Gestor de Idiomas, Universidad de Guantánamo, Cuba. E-mail: zoilag@cug.co.cu 


\section{Introducción}

El aprendizaje integrado de contenido y lenguaje (AICLE) es una herramienta pedagógica que promueve el uso de lenguas extranjeras como medio de aprendizaje, a la vez que promueve la adquisición de habilidades idiomáticas como parte del proceso de aprendizaje en sí (Coyle, 2010).

La imbricación del contenido de las asignaturas del currículo base de cada carrera con la asignatura idioma inglés, que es la segunda lengua que se estudia en las universidades cubanas, tiene como objetivo lograr que los alumnos adquieran conocimiento de la materia curricular y desarrollen su competencia en un idioma que no sea el lenguaje normal de instrucción. A propósito, para los alumnos universitarios, estudiar el contenido curricular mediante la consulta de textos y documentos escritos en lenguas extranjeras resulta provechoso, pues, a la vez que consolidan el vocabulario relacionado con su perfil profesional, consultan materiales actualizados y relevantes para el desarrollo de competencias de lectura, comprensión y expresión en lengua extranjera en el contexto de su especialidad.

En la Universidad de Guantánamo los profesores del Departamento de Idiomas, de acuerdo con lo establecido en el plan de Estudios D, desde 2009 y hasta el curso pasado (2016-2017), establecieron la necesidad de vincular los contenidos de las clases de la especialidad y las asignaturas base de cada currículo con el idioma inglés, mediante la implementación de una estrategia de idiomas que traspasaba los límites curriculares, basada en la cooperación entre el departamento de idiomas y otros departamentos docentes. Ello permitió ahondar en la interacción entre los miembros del claustro de cada carrera y especialidad con los profesores de inglés. Cabe destacar que tal orientación ha sido siempre cumplida fielmente por los profesores de la Facultad Agroforestal (anteriormente Facultad Agroforestal de Montaña), mediando siempre la flexibilidad y la capacidad de adaptación y creatividad de su claustro, así como su compromiso con la mejora de la calidad de la docencia.

La implementación de la metodología para el AICLE tiene como objetivo que los estudiantes universitarios logren un nivel aceptable 
de habilidades comunicativas bilingües. Favorecer (en el caso de Cuba) la enseñanza del idioma inglés como lengua extranjera, mediante la autopreparación y el estudio de las asignaturas del currículo, es un objetivo práctico que aumenta el nivel de exposición al inglés como lengua extranjera, lo que conduce a un incremento de la competencia lingüística. Es una tarea de mediana complejidad, pero una vez que el estudiante se familiariza con el vocabulario relacionado con la especialidad, aumenta su competencia comunicativa en lengua inglesa.

Los beneficios del AICLE pueden ser percibidos en términos de una mejora en la conciencia cultural, internacionalización, competencia lingüística, preparación para el estudio y la vida laboral, y mayor motivación.

La implementación del AICLE como enfoque educativo en el plan de estudios ofrece una amplia gama de ventajas para el proceso de enseñanza y aprendizaje, pues motiva a alumnos y profesores a aprender el idioma extranjero al utilizarlo para aprender/impartir el contenido de las asignaturas, estimulando la asimilación de la materia por medio de un enfoque novedoso y desafiante, que provee información relacionada con la asignatura, pero intercambiando el lenguaje de instrucción.

Una asignatura en la que se implemente el AICLE debe combinar los siguientes elementos, preceptos establecidos por Coyle, que denominara Currículo 4C:

- Contenido: progresión en el conocimiento, habilidades y comprensión relacionada con elementos específicos de un plan de estudios definido.

- Comunicación: usar el lenguaje para aprender mientras se aprende a usar el lenguaje.

- Cognición: desarrollar habilidades de pensamiento que vinculen la formación de conceptos, la comprensión y el lenguaje.

- Cultura: exposición a costumbres, maneras de pensa, y conocimientos culturales foráneos (Coyle, 1999). 
Para los profesores de un contexto de enseñanza de ILE, las clases que se sirven del AICLE deben:

- Integrar habilidades receptivas y productivas.

- Tener audiciones o lecturas relacionadas con la especialidad; por ejemplo, en las clases de práctica agrícola, para estudiantes de la carrera Agronomía, los textos y medios de enseñanza seleccionados para la clase de AICLE deben guardar relación con la especialidad.

- Tomar en cuenta estilos de aprendizaje de los estudiantes para diseñar las actividades.

El profesor de la asignatura también debe aprovechar las oportunidades del contenido para desarrollar habilidades lingüísticas. Esta es la esencia dela capacitación de profesores que imparten sus clases con la metodología del AICLE. A continuación, se presentan ideas valorativas acerca de la utilidad de una clase con la metodología del AICLE para expandir el perfil educacional de las carreras, diversificar los modos de impartir clases, incrementar el entendimiento intercultural y la motivación de los estudiantes, a la vez que aumentar el vocabulario de ILE. También se provee un ejemplo de clase para los estudiantes de primer año de la carrera Ingeniería Agrónoma, que fue diseñada teniendo en cuenta el enfoque metodológico del AICLE.

\section{Desarrollo}

Una clase con la metodología del AICLE propiamente dicha no ha sido impartida por los profesores de la Universidad de Guantánamo porque, de acuerdo con la bibliografía consultada, esta debe ser impartida totalmente en idioma inglés. En cambio, en función de adaptar las clases a nuestra realidad educativa, en los años en que el Plan de Estudios D estuvo vigente, en la capacitación a los profesores de los departamentos de la Facultad Agroforestal de Montaña, en aras de implementar la estrategia de idioma inglés, se les impartieron talleres y clases metodológicas demostrativas, para vincular los contenidos de las asignaturas que impartían, mediante la orientación 
para consultar como parte del estudio independiente bibliografía escrita en ese idioma, o directamente en clase hacer preguntas acerca del contenido, que se formulaban en inglés. Esto se identificaba como Instrucción Basada en el Contenido e igualmente perseguía el objetivo que los estudiantes analizaran el contenido y los aspectos del ILE en igual medida.

Una clase que emplee la metodología para el AICLE a menudo consta de cuatro etapas.

I. Identificar el idioma.

2. Identificar y organizar el conocimiento: los mejores textos son aquellos acompañados por ilustraciones, para que los estudiantes puedan visualizar lo que están leyendo.

3. Procesar el texto: la estructura del texto se utiliza para facilitar el aprendizaje; se recomienda que el profesor destaque el lenguaje útil (indicadores textuales para presentar el tema, ejemplificar, comparar y contrastar, etc.) en el texto y lo categorice según la función.

4. Tareas o actividades: enfocadas a desarrollar el lenguaje y el contenido básico, que debe guardar relación con la asignatura; al finalizar la clase el estudiante debe ser capaz de reproducir la esencia del texto en sus propias palabras (Lesca, 20I2).

Las lecciones de AICLE, como puede deducirse, deben ser impartidas por un profesor conocedor de esa metodología y deben utilizar material directamente relacionado con una asignatura. El procesamiento de la información debe apoyar la producción del lenguaje de la misma manera que una lección de ILE, mediante el uso de técnicas para comprender textos, o para la comprensión oral del idioma inglés, pero en la Universidad de Guantánamo (UG) un gran porcentaje de profesores no está preparado para hacerlo debido a sus deficiencias en inglés. La teoría puede ser sólida, pero aún persisten preguntas sobre cómo la teoría se puede traducir de buen modo en la práctica en el aula.

En este sentido, los graduados de Agronomía son los futuros encargados de desarrollar la ciencia y la tecnología agrícola, educar y 
formular políticas relacionadas con el ámbito agrícola de nuestro país, cuya base productiva es eminentemente agrícola. Para desempeñar tan importante rol social deben desarrollar habilidades para el aprendizaje mediante la consulta de bibliografía actualizada, que se publica primordialmente en idioma extranjero, así como habilidades para el intercambio y la cooperación con homólogos de habla inglesa. Conviene prepararles en temas tan diversos como: ecología, gestión, manejo, utilización de forraje tropical, modelación del crecimiento de cultivos, atributos de las plantas, preservación de los terrenos de cultivos, suelos, respuesta fisiológica de los cultivos al cambio climático y al estrés ambiental, fitomejoramiento, genética, biología molecular, principios y prácticas agronómicas, en fin, la lista puede ser extensa.

En la UG todos los departamentos, incluido el Departamento de Agronomía, proporcionan equipos informáticos para que los estudiantes de pregrado accedan a internet. Los laboratorios informáticos para estudiantes están ubicados en el segundo piso de la sede central, pero existen otros en las diversas facultades, que los estudiantes pueden usar para descargar información. En la residencia hay otro laboratorio de estudio, porque se hace todo lo posible para proporcionar a cada estudiante de pregrado un área de estudio para descargar libros y otros materiales relevantes.

A ello se suman las bibliotecas digitales, las bases de datos, a las que todas las universidades cubanas están conectadas por fibra óptica; existen más de 550 puntos wifi, y una red de más de 130.000 usuarios conectados a internet. Además, como refirió Walter Baluja García, director de informatización del MES, en la Mesa Redonda del I4 de noviembre de 2017: "se aspira a que, para el 2018, se pueda interconectar la red nacional universitaria con otras redes científicas y académicas del país y poder intercambiar los servicios especializados de cada uno de los organismos, para que los jóvenes puedan tener acceso a información de primera mano y contenidos más pertinentes" (Juventud Rebelde, 2017).

Con la implementación del Plan de Estudios E en la carrera, en el curso 2016- 2017 se ha ido repensando con profundidad las materias 
y la forma de impartirlas, en correspondencia con el desarrollo del modelo económico y social cubano y las nuevas tecnologías. El nuevo modelo curricular propone otra perspectiva de enseñanza, en la cual el alumno gestiona su propio aprendizaje, se reducen las horas clase y se enfatiza en la esencialidad de los contenidos. Las transformaciones curriculares exigen también cambios en las dinámicas de trabajo y la cultura profesional de los docentes. El papel del profesor, en este nuevo plan, es dotar al estudiante de la capacidad, las habilidades y las posibilidades de obtener y de aprender por sí mismo, e incitar a los alumnos a la autogestión de sus conocimientos.

Parece oportuno entonces asumir el reto de integrar los conocimientos básicos de asignaturas puramente técnicas con el ILE, que aporta a los estudiantes cultura general integral, una fortaleza del plan E que garantiza la transversalidad entre los contenidos, ya sea de la manera en que se hacía tradicionalmente en el plan D, o con clases desafiantes que inserten el AICLE, potenciando la sistematización individual.

A continuación, se presentan dos clases que utilizan la metodología del AICLE, planificadas e impartidas en 2018 a los estudiantes de segundo año de la carrera Ingeniería Agrónoma por la autora, que es profesora de ILE.

Topic: Tillage systems.

Type of lesson: workshop.

Time allotted: $90 \mathrm{~min}$.

Lesson aim: To achieve greater understanding of sustainable agricultural practices.

Teaching means: text- excerpt from page 40 Book National Agronomy Manual, $4^{\text {th }}$ edition issued February 20 I I by The U.S. Department of Agriculture (USDA). Two pictures.

Language aim: To expand the lexical field related to sustainable agricultural practice.

Skills: reading scanning, analytical thinking, summarizing skills, deductive reasoning. 
Stage I.- the professor presents 2 pictures related to agricultural practices (I good/I bad) and ask them to choose the good/ sustainable practice.

Stage 2.- Activity I Explain the reasons for picking that specific picture. (group work- cooperative work).

Stage 3.- Activity 2 Students read the text which deals with a topic related to good agricultural practices.

- Answer gist questions.

- Compare answers with partners.

- Brainstorm more differences between good/ bad agricultural practices.

- Identify in the text the markers to compare and/ or contrast (as opposed to, in comparison, better than...).

Stage 4.- Activity 3 Students are asked to fill a grid provided by the professor using information of the text. (Pair work).

Stage 5.- Activity 4 Using the grid essentials students are asked to summarize the text in no less than 250 words highlighting what they learned in class about sustainable agricultural practices.

Stage 6.- Conclusions of the lesson, a time to correct the errors made in language, congratulate, criticize, and assign marks.

El texto con que se trabajó en la clase es el siguiente:

\section{Tillage systems}

The tillage system is an integral part of the cropping management system for a farm. The type, number, and timing of tillage operations have a profound effect on soil, water and air quality. Tillage systems vary widely depending on the crops, climate, and soils. The impacts of tillage on crop residue vary greatly depending on implements used; implement adjustments and the number of tillage trips.

Conservation tillage as defined by the Conservation Technology Information Center is any tillage and planting system with 30 percent or more residue cover remaining on the soil surface after planting 
to reduce soil erosion by water. Where soil erosion by wind is the primary concern, at least I,000 pounds per acre of flat small grain residue equivalent are left on the soil surface during the critical wind erosion period.

\section{Residue management practices}

Residue management practices that typically meet the conservation tillage definition include:

- No-till, direct seed, and strip-till-these systems manage the amount, orientation, and distribution of crop and other plant residues on the soil surface year-round, while growing crops in narrow slots, or tilled or residue-free strips in soil previously untilled by full-width inversion implements. The soil is left undisturbed from harvest to planting except for nutrient injection. Seeds are placed in a narrow seedbed or slot made by coulter(s), row cleaners, disk openers, in row chisels, or rot tillers where no more than one third of the row width is disturbed. Weeds are controlled primarily with herbicides. Row cultivation for emergency weed control should utilize undercutting implements that minimize residue burial.

- Ridge-till-Managing the amount, orientation, and distribution of crop and other plant residues on the soil surface year-round, while growing crops on pre-formed ridges alternated with furrows protected by crop residue. The soil is left undisturbed from harvest to planting except for nutrient injection. Planting is done in a seedbed prepared on ridges with sweeps, disk openers, coulters, or row cleaners. Residue is left on the surface between ridges. Weed control is done with herbicides or cultivation or both. Ridges are rebuilt during row cultivation.

- Mulch-till-Managing the amount, orientation, and distribution of crop and other plant residue on the soil surface year-round, while growing crops where the entire field surface is tilled prior to planting. Tillage tools such as chisels, field cultivators, disks, sweeps, or blades are used. Weed control is done with herbicides or cultivation, or both. 


\section{Crop residue management}

Despite considerable acceptance of these definitions there is still some confusion as to the meaning of conservation tillage. Crop residue management is defined as: Any tillage and planting system that uses no-till, ridge-till, mulch-till, or other systems designed to retain all or a portion of the previous crop's residue on the soil surface. The amount required depends on other conservation practices applied to the field and the farmer's objectives.

Tillage systems, whether a conservation tillage system or some other system that retains little, if any, residue is an important part of a crop production system. Crop response to various tillage systems is variable and the variability if often difficult to explain because so many aspects of crop production are influenced by tillage. In addition, weather variability is an additional factor which influences crop production from one year to the next. Items to consider in designing a conservation tillage system include the following:

- Soil temperature-Crop residue insulates the soil surface from the sun's energy. This may be a plus at planting time or may delay planting and/or lead to poorer germination. If this is a concern, the use of planter attachments to remove residue from the row area will improve the situation. Later in the growing season crop residue on the soil surface may lower the soil temperature, resulting in increased crop growth and yield.

- Allelopathy - This refers to toxic effects on a crop because of decaying residue from the same crop or closely related crop. Crop rotation can eliminate this problem. The use of planter attachments to remove the residue from the row area may reduce the problem. Allelopathic effects can also be beneficial by reducing competition from some weeds.

- Moisture - When crop residue is on the soil surface, evaporation is reduced and water infiltration is increased. Although this may be a disadvantage at planting time in some areas, the extra soil moisture may increase yields if a dry period is encountered later in the growing season. No-till systems often have more water 
than conventional systems available for transpiration later in the growing season, resulting in increased yields.

- Organic matter - Soil organic matter tends to stabilize at a certain level for a specific tillage and cropping system. Each tillage pass aerates the soil, resulting in the oxidation of decaying residues and organic matter. Crop residue left on the soil surface in no-till or ridge-till systems decomposes slower, resulting in increased organic matter levels in the upper few inches.

- Soil density - All tillage systems have some effect on soil density. Systems that disturb the plow layer by inversion tillage or mixing and stirring temporarily decrease soil density. However, after the soil is loosened by tillage, the density gradually increases due to wetting and drying, wheel traffic, and secondary tillage operations. By harvest the soil density has returned to almost the same density as before tillage operations started. Cropping management systems that use several tillage operations can create a compacted layer at the bottom of the plow layer. If the compaction is excessive, then drainage is impeded, plant root growth is restricted, there is reduced soil aeration, herbicide injury may increase, and nutrient uptake may be restricted.

No-till systems have a higher soil density at planting time than other systems because the plow layer is not disturbed to form a seedbed. This higher density seldom has any effect on germination, emergence, and subsequent crop growth. Many times the crop will benefit from this because these soils retain more available moisture.

- Stand establishment - Regardless of tillage system uniform planting depth, good seed to soil contact, and proper seed coverage is needed to obtain a good stand. Coulter and/or row cleaners may be needed to ensure a good stand in a no-till system. In addition, extra weight and heavy-duty down-pressure springs may be needed for the planter or drill to penetrate undisturbed soil, especially under less than ideal moisture conditions.

- Fertilizer placement - Starter fertilizer (nitrogen and phosphorus) is generally recommended to help overcome the effects of lower soil temperatures at planting time. If fertility levels $(\mathrm{P}, \mathrm{K}$, and 
$\mathrm{pH}$ ) are at maintenance levels before switching to a conservation tillage system, fertility should not be a problem. In a no-till system surface application of phosphorus and lime will result in stratification of these nutrients, but this has not shown to affect crop yield. It is generally recommended that nitrogen be knifed into the soil in a no-till system, or a nitrogen stabilizer be used. Surface-applied nitrogen may volatilize and be lost if a rain does not move the nitrogen into the soil profile shortly after application.

- Weed control - Controlling weeds is essential for profitable production systems. With less tillage, herbicides and crop rotations become more important in obtaining adequate weed control. Weed identification, herbicide selection, application rate, and timing are important. A burn-down may be needed in no-till and ridge-till systems. A change in weed species can be expected in no-till and ridge-till systems. Perennials may become more evident but usually can be controlled with good management. The combination of post-applied herbicides and bioengineered crops has made weed control much easier, even in a no-till system (USDA, 20II, p. 40).

En términos generales, los resultados que se obtienen de este tipo de clases son bastante satisfactorios, porque proveen un marco para que los estudiantes se sientan libres para expresarse en lengua inglesa, haciendo uso de sus conocimientos idiomáticos en un ambiente desafiante, pero no intimidante, que les estimula para probar sus habilidades de comprensión lectora y de valoración crítica de temas relacionados con su práctica laboral. A partir del análisis realizado mediante la observación directa y las entrevistas informales a los estudiantes, ellos destacaron sentirse retados y apreciaron el trabajo en grupos cooperativos y el aprendizaje a través del idioma extranjero.

Otro ejemplo de clase diseñada tomando en cuenta un enfoque del AICLE se presenta a continuación; esta integra la audición a la lectura de texto.

Topic: Self access to knowledge at the UG. 
Type of lesson: practical - to be developed at the laboratory I of the Center of Languages of the UG for the students self-access to English multimedia and language learning.

Time allotted: $90 \mathrm{~min}$.

Lesson aim: To discuss the variety of information search services and means available in the University of Guantánamo to facilitate an academic research.

Teaching means: text- excerpt of the At Your Pace III Learning to Learn Through English textbook Unit 4 page 3 I.

Language aim: To practice the markers for negotiating and debatingdevelop fluency in ESL and help students to become independent learners focusing on creativeness. (markers on Appendix I p. 78 At Your Pace III Learning to Learn Through English textbook).

Skills: listening, reading scanning, analytical thinking, summarizing skills, deductive reasoning.

Stage I.- the professor introduces the topic explaining the objective of this lesson and the importance of libraries and digital information pages and resources at the UG.

Stage 2.- Activity 2 page 33 to 35 At Your Pace III (the book can be found on the English files at http:// multimedia.cug.co.cu/ ingles. The activity reviews an UNAIDS webpage and is intended for group discussion.

Stage 3.- Activity 3 Aided by the debate and the printed and digital webpage the students are asked to write an outline of the text on pages 33 to 35 . The teacher will lead them to:

- Answer gist questions.

- Compare answers with partners.

- Brainstorm.

Stage 4.- Activity 4 page 37 At Your Pace III.

Stage 5.- Final task. Using the outline, students are asked to summarize the text in no less than 250 words highlighting what they learned in class using the markers for the different parts of an academic text. 
Stage 6.- Conclusions of the lesson, Activity 5 page 39 items a) and b) only of the At Your Pace III textbook. This is the adequate moment to correct the errors made in language, congratulate, criticize, and assign marks.

Las clases enfocan la atención en las habilidades relacionadas con la lectura, pero a la vez se trabajan, derivado de la lectura, las otras habilidades. En este segundo ejemplo la audición que se recomienda es parte de un CD complementario del mismo libro con que se trabajan las actividades de lectura y se presenta al inicio de la unidad.

A propósito, se espera que, como parte de la metodología AICLE, la disciplina idioma inglés sea orgánicamente insertada en el proceso de enseñanza/aprendizaje de las otras asignaturas, para que los estudiantes desarrollen, mediante el uso del idioma, una independencia cognitiva en el contexto académico. Actualmente, los centros de idiomas son los departamentos que rigen la enseñanza del ILE en las universidades cubanas, y como parte de las tareas de estos centros se prevé que la docencia esté orientada, de acuerdo con la concepción de la enseñanza comunicativa de lenguas, a la variante nocional-funcional, que tiene como objetivo lograr la competencia comunicativa (lingüística, discursiva, sociolingüística y estratégica) de los estudiantes en el dominio integrado de las cuatro habilidades generales del inglés, según lo establecen los descriptores del Marco de Referencia Europeo.

Los objetivos del programa actual de idioma inglés enfatizan en el lenguaje interactivo para comprender conversaciones, discursos orales, participar en conversaciones, hacer presentaciones, así como para comprender el sentido del material escrito y solicitar y ofrecer por escrito información personal, familiar y acerca de temas habituales, utilizando los conectores básicos.

Es muy importante que se prepararen actividades integradoras que permitan la interacción de los estudiantes en grupo, en equipos, y en parejas. Es conveniente, igualmente, que se preste especial atención a las estrategias de aprendizaje y al estudio independiente como elementos reforzadores del proceso. 


\section{Conclusiones}

Si se aspira a lograr altos niveles de motivación en nuestros alumnos y éxito en la práctica docente, se debe redoblar los esfuerzos por presentar los contenidos de manera amena y que provoquen la necesidad de consultar fuentes alternativas en el autoestudio y para su preparación profesional personal. Al planificar a través de contextos AICLE, se debe hacer algunos cambios, por lo tanto, las clases de ILE basadas en la gramática y las funciones comunicativas deben transformarse en función de un enfoque diferente para la enseñanza/aprendizaje.

De la misma manera, se debe desarrollar cuidadosamente un plan mediante el aprendizaje cooperativo, es decir, muchos elementos se deben modificar, como el enfoque pedagógico, el plan de estudios curricular y algunos factores organizacionales. Además, para el éxito de la tarea, es requisito indispensable la integración del trabajo del profesor de idiomas y del profesor de asignaturas de la carrera, no solo por razones curriculares, sino también por los efectos positivos en la instrucción de los alumnos.

En este sentido, la implementación de la metodología AICLE compromete a los profesores de los departamentos de la carrera de Ingeniería Agrónoma a capacitarse e involucrarse, y a renovar sus métodos de enseñanza, trabajando en conjunto con los profesores del departamento de idiomas. Esta imbricación promete resultados beneficiosos en los procesos de enseñanza/aprendizaje.

\section{Referencias bibliográficas}

Coyle, D. (1999). Theory and planning for effective classrooms: supporting students in content and language integrated learning contexts. In J. Masih (Ed), Learning Through a Foreign Language. London: CILT.

Coyle, D., Hood, P. y Marsh, D. (2010): CLIL Content and Language Integrated Learning. New York: Cambridge University Press.

Eurydice Report. (2006). Content and Language Integrated Learning (CLIL) at school in Europe. European Commission. Recuperado el I5 de marzo de 2010 de http://www.teachingenglish.org.uk/article/content-languageintegrated-learning 
Mesa Redonda La Educación Superior cubana en el actual curso escolar. Juventud Rebelde, noviembre de 2017 ISSN: 0864-I4I2 recuperado de http:// www.juventudrebelde.cu

Lesca, U. (2012). An introduction to CLIL: Notes based on a CLIL course at British Study Center - Oxford. Recuperado en diciembre de 2017 de http://www.itis. biella.it/europa/pdf-europa/CLIL Report.pdf

USDA (20I I). National Agronomy Manual, $4^{\text {th }}$ edition issued February 20I I. The U.S. Department of Agriculture. Recuperado de https://www.nrcs. usda.gov/Internet/FSE DOCUMENTS/stelprdbI043208.pdf 